\title{
Stóhr Lóránt
}

\section{Egy közép-európai vegetáció leírása}

\section{Szerzô}

Stôhr Lóránt (1974) az Élet és Irodalom filmkritikusa, a Színház-és Filmmúvészeti Egyetem docense. Szakterülete: filmmelodráma, Fassbinder életmúve, dokumentumfilm, kortárs film. E-mail: stohrlorant@szfe.hu

https://doi.org/10.31176/apertura.2018.13.1.2 


\section{Stóhr Lóránt}

\section{Egy közép-európai vegetáció leírása}

[Varga Balázs: Filmrendszerváltások. A magyar játékfilm intézményeinek átalakulása 1990-2010.

L'Harmattan, Budapest, 2016]

A magyar filmtörténetíráson számtalan lyuk tátong a mozgófényképezés hazai kezdeteitôl napjaink digitális multiplexmozijáig. Az alapkutatások elmaradása részben a filmtörténetírás hazai akadémiai intézményesülése jelentôs megkésettségének, részben a Magyar Filmtudományi Intézet Filmarchívummá alakításának tudható be. A kilencvenes években lényegében nem volt Magyarországon a filmelméletnek otthont adó intézmény: sem kutatóintézet, sem önálló egyetemi tanszék. Filmes kutatóintézet továbbra sincsen, bár a Magyar Nemzeti Filmarchívum idei átszervezése és az új vezetés létrejötte reményekkel töltheti el a filmelmélet képviselóit és a filmrajongókat. ${ }^{[1]}$ A kétezres évek környékén létrejövô filmes tanszékeken elinduló rendszeres kutatások még csak szórványos eredményeket hoztak a magyar filmtörténet feldolgozásában. Az aktuális hazai filmtörténeti kutatások egyik vakfoltja az intézménytörténet. Varga Balázs Filmrendszerváltások címú kötete az 1989 utáni intézménytörténet elsô, alapos monografikus feldolgozása, s mint ilyen nemcsak hiánypótló mú, de egyúttal iránymutató is kíván lenni a tekintetben, hogyan nyúljon a kortárs filmtörténész a filmes intézmények kérdéséhez.

2016 a kortárs magyar filmpolitika és filmfinanszírozás elmélete és intézménytörténete szempontjából gazdag évnek bizonyult, amelyben nagy szerepet játszik, hogy az MMK megszûnése és az MNF megalakulása óta eltelt évek lehetôséget adtak az elôbbi kellôen távlatos értékelésére, az utóbbi mostanáig elért eredményeinek számbavételére. Varga kötete mellett két doktori disszertáció is befejezésre és megvédésre került a Színház- és Filmmúvészeti Egyetemen. Joó Tamás ${ }^{[2]}$ és Foktôi János ${ }^{[3]}$ értekezései remekül kiegészítik Varga Balázs kötetét, nemcsak további hasznos forrásként szolgálnak az adatok feldolgozásában és a folyamatok megértésében, de sajátos szempontrendszerükkel árnyalják, kiegészítik és bírálják Varga filmtörténészi látásmóddal megírt könyvét, ezért jelen kritikám megírásában számomra is alapvetô szakirodalomként szolgálnak.

A kötet kapcsán az elsô kérdés a címmel kapcsolatban merül fel. A magyar játékfilm intézményeinek átalakulása 1990-2010 - szól a kötet alcíme, amiból egyrészt kiviláglik, hogy a szerzô hangsúlyosan a (nagy)játékfilmgyártás, -forgalmazás, -bemutatás kérdéseire összpontosít, másrészt az is, hogy az a két évtized áll a kutatás fókuszában, amelyet a Magyar Mozgókép (Köz)alapítvány ${ }^{[4]}$ idôszaka fémjelez. A szerzô valóban tartja magát a nagyjátékfilm intézményi kérdéseihez (a címhez illôen helyenként kitérve a kisjátékfilmezésre, de szigorúan mellôzve a dokumentum-, animációs-, ismeretterjesztô-, kísérleti és egyéb filmes formák intézménytörténetét), ugyanakkor üdvözlendô 
módon kiterjesztette kutatását egyfelôl a rendszerváltást közvetlenül megelôzô évekre, ami nélkül érthetetlen volna az 1990-nel kezdôdô idôszak, másfelôl a 2010 utáni, Andy Vajna nevével fémjelezhetô filmtámogatási érára, ami pedig kontrasztot biztosít az MMK közel húsz éves történetéhez, és rálátást enged a kortárs magyar film intézményi és esztétikai folyamataira. A folyamatok és az adatsorok többnyire 2014-ben zárulnak, ám néhány helyen 2010 (a legnézettebb magyar filmek - 133 ${ }^{[5]}$ ) vagy 2012 (díjak, fesztiválszereplések - 158) az utolsó feldolgozott év. Varga hozhatta volna azt a döntést, hogy 2011-ben, az MMK megszüntetésével fejezi be történetét, ám a filmtörténész szakma örömére nem ezt tette, kitért az MNF elsô időszakára is, amely kibôvítve a filmfinanszírozási rendszerek körét gazdagabb lehetôséget adott neki az összehasonlításokra - viszont ezt a címben sem ártott volna jelezni.

A filmtörténetíráson belül az intézménytörténet az 1970-80-as években virágzott fel az Egyesült Államokban. A tisztán kapitalista viszonyok között múködô hollywoodi film intézményeinek történeti leírása egyaránt helyet adhatott a marxista és a tömegközönség igényeivel magyarázott piaci értelmezéseknek. ${ }^{[6]}$ Varga kötete a magyar film rendszerváltás utáni intézménytörténetérôl írt monográfiát, ám a korábbi bevett gyakorlatokhoz képest újszerú módszerrel tette. Az ELTE filmtörténésze nem korlátozta magát a szúken vett intézménytörténetre, amely a gyártás, forgalmazás, bemutatás intézményeit leíró jelleggel, statikusan vizsgálja, hanem a maga dinamizmusában igyekezett leírni a (játék)filmkultúrát, az aktuális filmkészítési trendeken mérve le az intézményi átalakulások hatását. Varga a magyar játékfilmkultúrát ökoszisztémaként írja le, „beleértve ebbe a finanszírozás, a gyártás, a forgalmazás és a bemutatás kérdéseit éppúgy, mint a kanonizáció problémáit" (8). Az ökológia terminussal a filmtörténetben ${ }^{[7]}$ az intézményrendszer, elsősorban a gyártás leírása kapcsán találkozhatunk, így például Jon Dovey a dokumentumfilmes ökoszisztémákat ${ }^{[8]}$ vizsgálja. Varga módszere rokonítható Dovey-éval, ám annál szélesebb ívú és átfogóbb. A magyar filmtörténész módszerét szembeötlố módon demonstrálta magával a szerkesztésével. A két részre tagolt kötet elsô részében a szerző az európai film támogatási rendszereinek és a kortárs nemzeti filmgyártások problémáinak vázlatos, a magyar filmet kontextusba helyezô bemutatása után a hazai filmfinanszírozás idôbeli változásait elemezte. A másodikban a finanszírozást biztosító intézményrendszernek a filmkészítésre gyakorolt hatásait vizsgálta a következő témakörök mentén: a koprodukciók, a szervízmunkák, a mozibemutatás, az éves filmmennyiség, a populáris film, a filmrendezők által képviselt trendek, a fiatal filmrendezôk pályára lépése, a kanonizáció, a filmfesztiválok és a filmek országképe. (A két rész ellátása címekkel, valamint a tartalomjegyzék és az egyes fejezetkezdetek tipográfiája jobban segíthette volna a tájékozódást a kötetben, az egyes gondolati egységek határainak könnyebb megértését.) A magyar filmkultúra sokféle „vegetációt” és „társulást” leíró ökoszisztémájából a befogadói oldal leírása hiányzik a legerôsebben: így csak utalásokban jelenik meg a filmkritika ${ }^{[9]}$ és a filmoktatás ${ }^{[10]}$ , valamint elmaradnak a közönségszociológiai vizsgálatok, amelyek együttesen segítenének megérteni, hogy a magyar játékfilmet a 25 év alatt milyen befogadói környezet vette körül. 


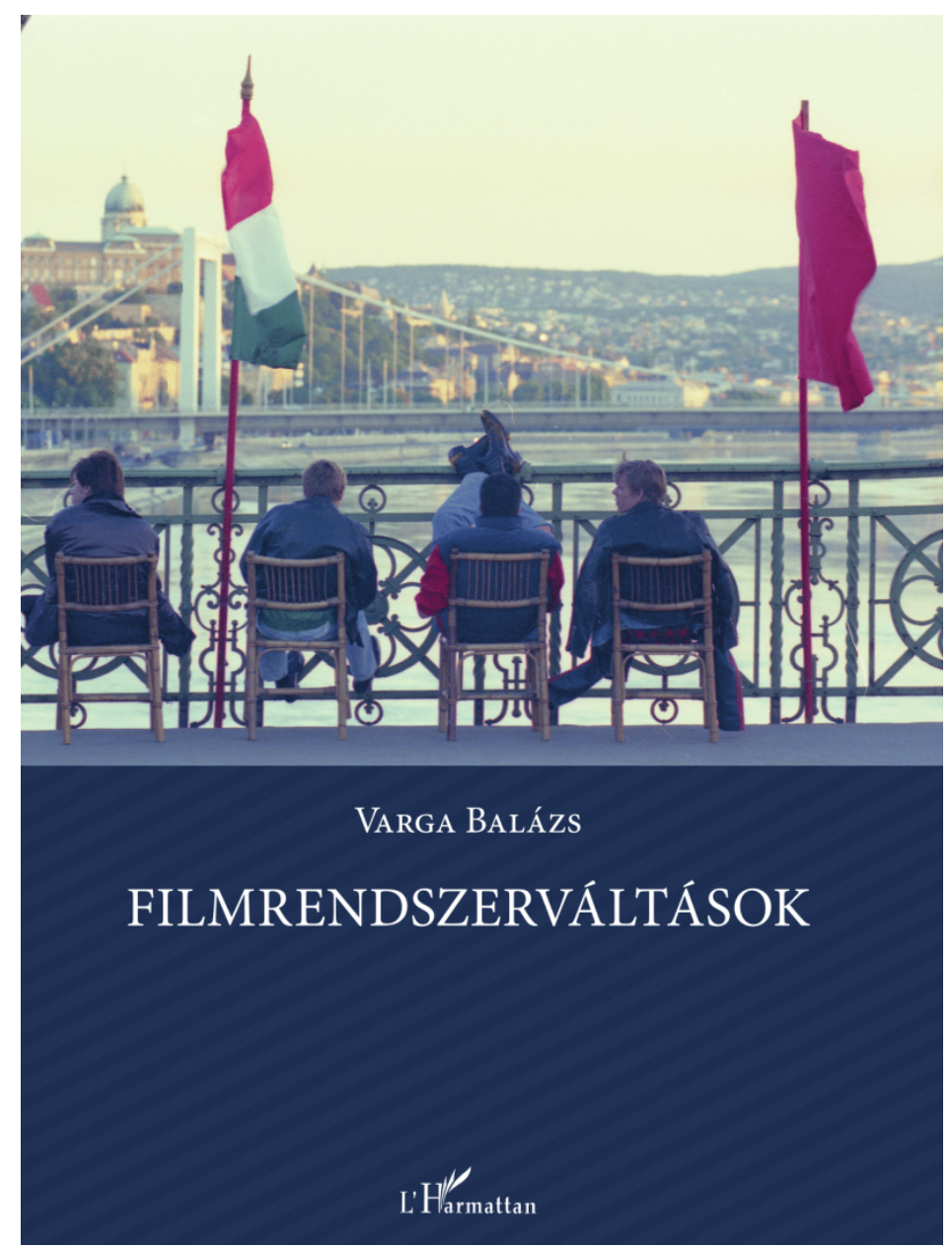

Varga Balázs: Filmrendszerváltások. A magyar játékfilm intézményeinek átalakulása 1990-2010 
A kötet első része, a szorosan vett intézménytörténet a rendszerváltást közvetlenül megelôző és a rendszerváltás utáni különböző filmtámogatási rendszerek történeti narratívába való elrendezését és teljesítményük értékelését tartalmazza. A Filmrendszerváltások mellett a két korábban említett doktori értekezés is részben ezt a feladatot célozza meg: Foktôi szövege nagyjából párhuzamba állítható Varga könyvének elsô részével, míg Joó írásának egyes, a filmpolitikát és a filmtámogatási alapokat tárgyaló fejezetei ezt a kérdést általánosabb perspektívából tekintik át összehasonlítva és mérlegre téve a különféle európai gyakorlatokat. Mindhárom szerzó a filmalapok és filmpolitikai gyakorlatok sikerességének megragadására törekszik, és e célból igyekszik szakmai indikátorokat azonosítani. Varga indikátorai közül a hatékonyság látszik a legerôsebb, legátfogóbb értékmérônek (67), amely mellett megjelennek, ám kisebb súlyt kapnak a humán értékek. Varga Balázs erōs filmtörténészi vénával megírt könyvében három, az egymást követô évtizedekhez igazodó korszak rajzolódik ki, amelyeket a szerzô a hatékonyság kritériumai mentén ír le és értékel: az 1990-es évek, amely az MMK megalakulásának és egy kiszámíthatóan alacsony támogatású filmfinanszírozási rendszernek az idôszaka, a 2000-es évek, amely az elôző idôszaknál nagyobb, ám kiszámíthatatlan finanszírozási összegek és a kormányzattal való folyamatos alkudozás, valamint a 2010-es évek, amelyet pénzügyi automatizmusok és a kormányzatnak a filmfinanszírozás kérdéseitól való közvetlen tartózkodása jellemeznek.

Az I. rész legizgalmasabb egysége az 1989 körüli - az elmúlt évek filmpolitikai csatározásai közben háttérbe szorult és elfelejtett - átalakulás értelmezése, amelyben Varga lényeglátóan mutat rá a történeti távlatból immáron jól érzékelhetô folyamatokra. Az egység legnagyobb tanulsága, hogy az átalakulás nem egyik pillanatról a másikra, nem egyetlen meghatározó döntéssel, hanem többlépcsôs folyamaton keresztül ment végbe: az elsô lépcsố a gazdasági válság és a filmiparra fordítható pénzek csökkenése miatt a Mafilm múködésének piacosítása, gyártási-szolgáltatási monopóliumának megszúnése volt, a második az új, magán filmgyártó cégek megjelenése, a harmadik, leglátványosabb a Magyar Mozgókép Alapítvány (MMA) ${ }^{[11]}$ megalakulása, a negyedik, valamivel megkésve, a stúdiórendszer felbomlása az MMA egyéni pályázatokra történő átállásával. A történeti leírásból világossá válik, milyen nehezen engedte el a filmszakma a korábbi évtizedekben sikeresen múködô, államilag dotált stúdiórendszert, miután megszabadult az államszocialista kultúrairányítás gyúlölt cenzúrájától.

Az I. rész második egysége a kétezres évekkel, a filmtörvény megszületésével és az MMK 2004 utáni ellentmondásos, sokat vitatott idôszakával foglalkozik. A nagy konszenzussal megszületett filmtörvénynek meglepően kevés teret szentel a szerző (Foktôi jogi téren rendkívül alapos értekezéséból e kérdésrôl behatóbban tájékozódhatunk), viszont hosszan és differenciáltan tárgyalja az MMK és a filmpolitika múködésének érzékeny területét. Az MMK múködésének alapvetô problémáját abban jelöli meg, hogy „,[n]agy volt az eltérés az ígért, tervezett és végül folyósított költségvetési támogatási összegek között" (49). Az MMK a kormányzatot lépéskényszerbe hozó, ám végzetesnek bizonyuló választ adott az ígért összegek elmaradására, jelesül azt, hogy „évrôl évre nagyobb összegú támogatásokról hozott döntést, mint amekkora költségvetési pénzt végül ténylegesen kapott” (51). A 2010-11 körüli sajtóbotrányok az MMK 
megszüntetéséhez politikai tôkét biztosító szalagcímeivel és sarkított megfogalmazásaival szemben Varga Balázs azt a fontos és erôs állítást teszi, hogy az MMK tartozása nem az állam által adott alapítványi pénzek „ellopásából” eredt, hanem a biztosított költségvetésen túli, a banki kamatok miatt egyre növekvô kötelességvállalásból.

Az MMK felszámolásához azonban, mint Varga helyesen rámutat, politikai döntésre volt szükség, hiszen akár úgyis határozhatott volna a 2010-ben hatalomra került Fidesz-KDNP-kormány, mint elôdje, hogy konszolidálja az MMK-t. Varga szerint a bizalom hiányzott az új kormányban az MMK vezetésével szemben, míg a bizalom megvolt Andy Vajna iránt, akit filmügyi kormánybiztosnak neveztek ki 2011 elején (59). Egyrészt igaz a szerző megállapítása, ugyanakkor a 2010 májusa utáni fejlemények abba az irányba mutatnak, hogy az MMK nem pusztán a felelôtlen gazdálkodása, hanem közalapítványi mivolta miatt is „elvesztette a bizalmat”, vagyis jogi státusza miatt is megszüntetésre került volna, mint ahogy több tucat más közalapítvány. ${ }^{[12]}$ A Fideszkormányzat 2010 óta a legtöbb állami intézmény vezetését lecserélte, a párthoz lojális embereket nevezett ki az élükre, így tehát nagy valószínúséggel a demokratikusan szerveződô, a vezetôségét és befolyását illetôen a kormányzattól elvileg független MMK-ra így is, úgy is a megszüntetés várt volna. A bizalom tekintetében igazán érdekes, hogy nem meglévő intézmények vagy új intézményes megoldások és filmpolitikai koncepciók iránt érzett bizalmat a kormány, hanem egyetlen személy, jelesül Andy Vajna iránt, akinek akkor még kevés tapasztalata volt a magyar és az európai állami filmfinanszírozással kapcsolatban. Az MMK utolsó idôszakának kulcskérdése, hogy mi lett volna, ha 2009-ben az MMK kuratóriumának elnöki pozíciójára jelentkező Andy Vajnát választja meg a tagság Kőrösi Zoltán helyett. Vajon ha a Fidesz-kormány Andy Vajnát találja az MMK élén, akkor meglett volna a bizalom a közalapítvány iránt? Bár erre a kérdésre nincs válasz, az MMK megszüntetésének értelmezése kapcsán érdemes volna felvetni ezt a dilemmát is. Varga a közalapítvány megszüntetésének okát késôbb az MMK-ra hárítja, amikor az „MMK bedólésérôl” ír (108), jóllehet az MMK-t végül bedöntötték, még abban az esetben is, ha jelentôs adósságokat halmozott fel az intézmény. A szerzố szerint az MMK múködését mindvégig egy alapvető ellentmondás hatotta át: az, hogy független szakmai szervezetként „nem tudott független lenni a politikától” (56). Ennek igazolásához hasznos lett volna összevetni az MMK-t más jelentôs, állami pénzekből gazdálkodó független szakmai szervezet múködésével, megvizsgálni, hogy vajon volt-e a rendszerváltás utáni magyar közéletben, szúkebben a múvészeti életben olyan szervezet, amelynek sikerült elkerülnie a politikától való bármiféle függést. S ha igen, ha volt ilyen szervezet, akkor mi volt a szerepe az MMK nem függetlenségében a múvészeti ág sajátosságainak (pl. nagy költségvetés, látványos eredmények), az MMK megalakulásakor az alapítványi formába elôre kódolt buktatóknak, a filmmúvészek rossz stratégiáinak. ${ }^{[13]}$

S ezzel el is érkeztünk a Filmrendszerváltások I. részének leginkább problematikus és leginkább vitatható egységéhez, a 2011 utáni filmpolitikát és filmfinanszírozást, elsődlegesen a Magyar Nemzeti Filmalap felállását és tevékenységét bemutató és értékelő fejezethez. Az elmúlt évek filmpolitikai vitái okán is erre az egységre hosszabban fogok összpontosítani kritikámban. Az az érzésem, hogy a szerzô egyébként erôs kritikai vénáját feledve néhány szempontra szúkíti 
vizsgálódását, és számos kérdést nem érint, amely árnyalhatná az új filmtámogatási rendszerrel kapcsolatos képet. A szerzô határozottan csak egyetlen vonását kritizálja az átmenetnek: a változás radikalitását. Az egyik példája a nagy presztízsú Magyar Filmszemle megszúnése, amelyet 2014-tôl kezdve a Magyar Filmhét váltott fel. Varga ezen a puszta ténymegállapításon felül nem jellemzi és értékeli a Magyar Filmhetet, amely kezdetben kaotikus szervezettségével, 2017-ben pedig a bemutatott filmek alacsony számával tûnt ki. A magyar film teljes spektrumát a nagyjátékfilmtól a kisjáték- és kísérleti filmen át a dokumentumfilmig felölelô, az egyes filmtípusokat reprezentatív mennyiségben felvonultató, a másutt még be sem mutatott alkotások első megmérettetésének és a magyar filmszakma legfóbb tájékozódási pontjának számító Filmszemle egészen más fajsúlyú fesztivál volt a magyar filmes közéletben, mint az egy-egy filmtípust néhány, változó színvonalú, többnyire már másutt bemutatott múvel képviselô Filmhét. A szerzô mentségére legyen mondva, mivel a kutatás 2014. évvel zárult, a Filmhét történeti áttekintésére és értékelésére nincsen módja.

Az új rendszer további gyengeségének tekinti a szerzô, hogy a filmgyártás finanszírozása két támogató szervezeten (MNF és Magyar Mecenatúra Program) keresztül megoldott, de a „nem gyártási szektor (forgalmazás, múvészmozik, fesztiválok és rendezvények, filmes lapok, szakkönyvkiadás, oktatás és képzés) továbbra is bizonytalan, és erősen forráshiányos.” (61) Az új (és régi) filmtámogatási rendszert azonban nem lehetséges kizárólag a forrásokkal való ellátottsága alapján értékelni. Bár nem tárgya a dokumentumfilm a kötetnek, mégis ezen a helyen érdemes lett volna kitérni, hogy milyen erôsen átpolitizált a Magyar Mecenatúra Program döntéshozatala, s hogyan járul ez hozzá a társadalomkritikus dokumentumfilm-múvészet elsorvadásához. ${ }^{[14]}$

Érdemes Varga egymást követô filmpolitikai rendszerek kapcsán hangoztatott pro és kontra nézeteit összevetni Foktôi János hasonló témakörben írt értekezésének szempontrendszerével. Foktôi bírálata elsôsorban arra irányul, hogy a Fidesz-kormányzat a filmet elsôsorban ipari és financiális szempontoknak rendelte alá, háttérbe szorítva egyéb, kulturális, morális, demokratikus értékeket. Foktôi a jogi szabályozás elemzésére támaszkodva kijelenti, hogy „a kormány a filmszakmai kérdéseket - bár azok elválaszthatatlanok egymástól - elsősorban nem a filmmúvészet, hanem a filmipar oldaláról közelíti meg”. ${ }^{[15]}$ A kezdetektól fogva ez a gondolkodás jellemzi a 2010 óta regnáló Fidesz-kormányzatot, s ez volt az oka a korábbi struktúra gyors felszámolásának. Foktôi szerint

a 2010. évet követố kormányzati kultúrpolitika a filmszakmával kapcsolatos „stratégiájának” meghatározásakor - elismerve és magáévá téve az állami szerepvállalás szükségességének elvét - a financiális kérdésekre tette a hangsúlyt és az Mktv. alaprendelkezéseit megtartva a támogatási rendszer átalakítására koncentrált. A már említett morális elemet [vagyis a filmszakmai teljesítmények erkölcsi megbecsülését] immár senki nem hozta szóba, és hogy mit gondolt arról a politika, azt nem szakmai vitaanyagok tartalmazták, hanem a filmszakmai önkormányzatiság rapid felszámolása mutatta meg. Az új kormány filmszakmai koncepciója lényegében az előzó szisztéma teljes átalakítására irányult, oly módon, hogy a magyar filmmúvészet tényleges irányítása 
egy sikeres, a filmszakmához értô, ámde a magyar filmmúvészet helyzetével még csak ismerkedô filmes szakember kezébe került. ${ }^{[16]}$

Joó Tamás élesebben fogalmaz a 2011 után felállt támogatáspolitikával kapcsolatban. Joó szerint az MNF a kormánybiztos irányításával a „gyakorlatban az amerikai és magánérdekeket a nemzeti érdeknél gyakran jóval hatékonyabban"[17] képviseli. A megállapításai alátámasztására egyrészt Andy Vajna magáncégeinek kétes ügyeit hozza fel, másrészt, és ez a fontosabb érv a 2010 utáni filmpolitikai korszak megítélésében, hogy a „támogatáspolitika a támogatási összegek aránya alapján is elsôsorban az egyébként is abszolút piaci fölényben lévô amerikai filmgyártás és filmexport gazdasági érdekeit szolgálja." ${ }^{[18]}$ Joó ezt a nézetét arra alapozza, hogy a magyarországi adókedvezményekból többet profitálnak a hazánkban forgató hollywoodi stúdiók, mint amennyi pénzt az állam a hazai filmgyártásra költ. A szervízprodukciók II. részbeli elemzése kapcsán még visszatérek erre a kritikára.

A 2011-ben életbe lépett filmfinanszírozási rendszer kulcsintézménye a nagyjátékfilmezést szelektív módon finanszírozó Magyar Nemzeti Filmalap. A Filmrendszerváltásokban Varga a következô tényezôk mentén értékeli az MNF múködését: a filmgyártás finanszírozásának kiszámíthatósága, a kormányzati politikától való függés, a döntéshozatali mechanizmusok, a gyártás tervezhetôsége és a „puha” emberi paraméterek. Az első négy „kemény” kritérium szerint az MNF a rendszerváltás utáni legsikeresebb filmalap a könyv szerint. Egy: az MNF a hatoslottó bevételeinek 80\%-ból gazdálkodik, tehát nincs kitéve az aktuális évi állami költségvetésnek. Kettő: mivel az MNF vezetésének nem kell alkudoznia a költségvetésról, nincsen közvetlen függés a kormányzattól. Három: az MNF „egyszerúbb, világosabb döntéshozatali rendszerre épít, amelynek nem lényege a szakmai szereplókkel való egyeztetés és konszenzuskényszer" (63). Négy: mivel a Filmalap nagyon szigorú gyártási tervet követel meg, cserébe a teljes gyártási költséget állja, a gyártó cégek nincsenek koprodukciókra, bankhitelekre kényszerítve. A négy szempontból az elsô pozitívumával kapcsolatban teljes konszenzus mutatkozik a szakemberek között, a második, a harmadik és negyedik esetében azonban érdemes lett volna kinyitni a vizsgálódás perspektíváját.

Az MNF a költségvetés tekintetében valóban nem függ a kormánytól, ám igen szemellenzôsnek kell lennünk, hogy ne lássuk, 2011 óta a magyar filmkultúrát kormánybiztos felügyeli, aki pozíciója elnevezéséból adódóan is közvetlenül be van kötve a kormányhoz. Az aktuális filmpolitika értékelésekor nem lehet mellôzni Andy Vajna egyéb tevékenységeit, állami támogatással felfuttatott kaszinóbizniszét és „FIDESZ-közeli” hitelekkel finanszírozott agresszív és gyors expanzióját a hazai médiapiacon, amelynek eredményeként állampárti propagandát néz az egyik országos kereskedelmi televízió és hallgat az országos és helyi kereskedelmi rádiók közönsége, olvas a megyei napilapokat forgató vidéki Magyarország. Valóban nincs szükség egyeztetésre, alkudozásra a kormánnyal, hiszen maga a kormány ül bent az MNF-ben, és felügyeli a filmszakmát a kormánybiztos személyében. Foktôi János másik, jogi jellegú érvet hoz fel amellett, hogy az MNF igenis erôsebben függ az államtól, mint az MMK függött.

Az MNF nonprofit gazdasági társaságként önálló jogi entitás, így feltételezhetôen 
független az állami beavatkozástól. A valóságban 100\%-os, azaz egyszemélyes tulajdonosként az állam közvetlenül gyakorolhatja tulajdonosi jogosítványait, ebben sem közgyúlés, sem vagyonkezelố testület (igazgatóság) nem „korlátozza”, a céget egyszemélyi felelôsként az állam által kinevezett vezérigazgató irányítja. Nem állítom, hogy ezzel a közvetlen beavatkozási lehetôséggel az állam az MNF eddigi múködése során a támogatások tartalmi (filmszakmai) kérdéseit illetôen élt volna, mint ahogy azt sem, hogy a támogatások elosztásában bármely politikai szempont érvényesült volna. Az MNF által nyújtott támogatások révén a társaság (végsố soron az állam) tulajdont (vagyoni értékú jogokat) szerez a támogatott projektekben, ezért - illetve más jogosítványok érvényre juttatása révén - véleményem szerint inkább koprodukciós partnernek tekinthető, mintsem mecénásnak. Mindezek alapján azt állítom, hogy a fô támogató szervezet nonprofit gazdasági társasági formájának ellenére az állami szerepvállalás direktebb módon jelentkezik, mint 2004-2010 között. ${ }^{[19]}$

A harmadik ponttal kapcsolatban: a Filmalap létrejötte, a Filmalap legfóbb döntéshozó testületének összeállítása tökéletesen mellôzte és mellózi a demokrácia játékszabályait. Az MNF felállításának nem volt része a szakmai konszenzuskeresés. A pályázatokat értékelô és a pályázati döntéseket meghozó öttagú Filmszakmai Döntôbizottság tagjait pályázat nélkül, határozatlan idôre nevezte ki a kormánybiztos, és személyük azóta csak részben változott (Havas Ágnes, Andy Vajna, Kovács András Bálint személye változatlan). Az MNF múködésének értékelésekor ezt a szempontot semmiképpen sem szabad figyelmen kívül hagyni. A negyedik szempont értékelésekor pedig kétséges, hogy az államnak kell-e 1-2 milliárd forint közvetlen támogatást adnia egy (populáris) filmnek (Pappa pia - 1 milliárd $\mathrm{Ft}^{[20]}$, A Viszkis - 1 milliárd $\mathrm{Ft}^{[21]}$, Kincsem több mint 2 milliárd Ft ${ }^{[22]}$, s erre még 20-25\% adókedvezmény jöhet rá), csak azért, hogy ne kelljen a producereknek koprodukciókat összehozniuk külföldi filmalapokkal, tévécsatornákkal, ami egyúttal a filmek nemzetközi forgalmazását vagy annak esélyeit is javíthatná. A harmadik és negyedik pontot érinti Joó Tamás egyik fố kritikája az MNF múködésével kapcsolatban, szerinte ugyanis számos esetben (a Filmszakmai Döntôbizottság tagjainak kinevezése, a döntéshozatal során a támogatói és támogatotti oldal üzleti érdekeinek találkozása stb.) felmerül az összeférhetetlenség gyanúja. ${ }^{[23]}$ Varga Balázs szempontjai között nem szerepel sem az összeférhetetlenség, sem a demokratikus játékszabályok vizsgálata, amit azzal magyarázhatunk, hogy a történetileg megvalósult magyarországi filmalapokat elsôsorban ideális állapotukban, a megcélzott modell felól értelmezi és értékeli, bár ez az érvelés, mint láttuk, az MMA és MMK esetében nem egészen állja meg a helyét. Bár bizonyosan nem ez a célja a szerzônek, a történeti távlat hiánya, az MNF ideális múködésének feltételezése miatt ${ }^{[24]}$ a Filmrendszerváltások egy fejlôdésnarratívát ír le, amelyet a (játék)filmgyártásra fordított egyre növekvő állami pénzek, a filmes döntéshozatal növekvô kiszámíthatósága és a politikától való növekvő függetlenség és növekvố szakmai elfogadottság jellemeznek. 


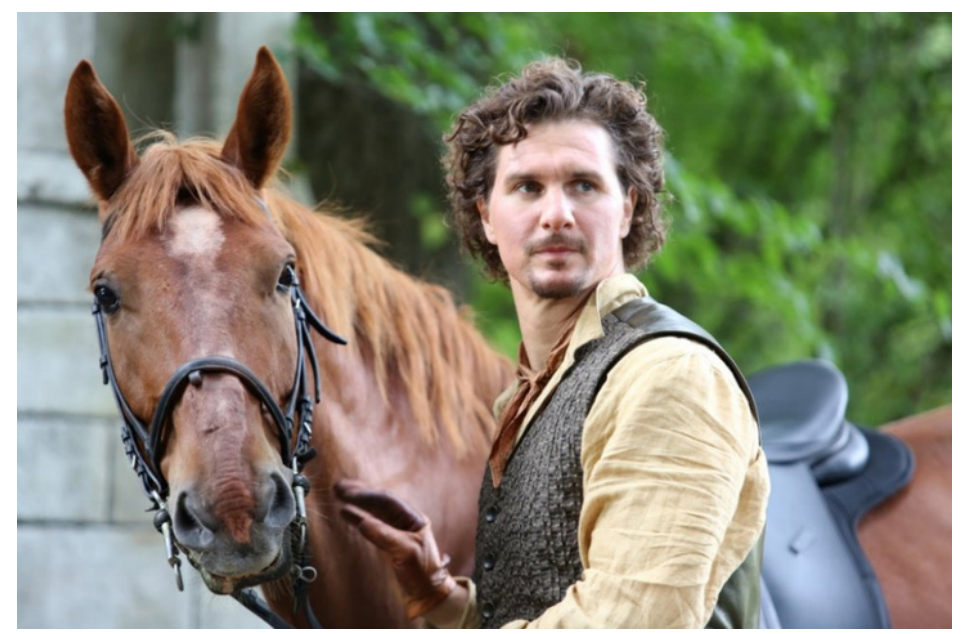

Kincsem (Herendi Gábor, 2017)

A Filmrendszerváltások második részében a szerző politikailag kevésbé érzékeny és vitatott területeket elemez, ahol filmtörténészi, filmkritikusi tehetségét és érzékenységét jobban ki tudja bontakoztatni, mint a 2010 utáni filmpolitika aláaknázott területén. A kötet óriási erénye, hogy a II. részben legelôször is kitekintést nyújt két másik közép-kelet-európai ország filmes intézményeire és a párhuzamos utak felrajzolásával mutatja be, hogy a rendszerváltás során lezajlott „intézményrendszerváltás” nem egyféle módon valósulhatott meg, ahogy ezt Magyarországon láttuk, s a különféle intézményi megoldások más és más játékfilmkultúrát eredményeztek. A cseh film kapcsán például lényegi összefüggésre mutat rá a piaci mechanizmusok szabályozó ereje, a felfutó szervízmunkák és a rendezók között lezajlott gyors generációváltás között, mely váltás ugyanakkor nem változtatta meg a cseh film húzóágazatát, a hazai nagy nézettséget eredményezô midcult filmek gyártását. A lengyel filmben pedig a belsô piac nagyságával támasztja alá a tömegfilmes múfajok rendszerváltás utáni gyors térhódítását, ami gyökeresen eltér a populáris filmkészítést lenézô magyar filmszakma 1989 utáni attitúdjeitôl. A két másik közép-kelet-európai ország bemutatása alátámasztja a szerzô izgalmas alapgondolatát, hogy ökoszisztémaként képzeli el és írja le a magyar filmkultúrát, s ennek megfelelōen az intézményrendszer „hardverjéhez” kapcsolódó számos témakör kibontását tûzi ki céljául.

A kötet erôsségei ott mutatkoznak meg igazán, ahol a választott módszer, a filmfinanszírozás módjainak és a filmkultúra folyamatainak összefüggései a kötet által nyújtott szúkös terjedelemben ki tudnak bontakozni. A második rész pontosan azért érzôdik némileg egyenetlennek, mert a témakörök kifejtettsége különbözố terjedelmú és mélységú. Az ökoszisztéma „sưrü leírása” jóval nagyobb hosszúságot, minden érintett témakör hosszabb és alaposabb kifejtést érdemelt volna meg. A fôszöveget képezô 170 oldal 33 fejezetre tagolódik, ami átlagosan nagyjából 5 oldalnyi hosszt jelent fejezetenként. Meggyőzôdésem, hogy hét (a táblázatokat leszámítva két és fél) oldalban a rendezôi életutakat, négy oldalban a Színház- és Filmmúvészeti Egyetemen folyó filmes képzést, hat oldalban a magyar filmek országképét lehetetlen a maga mélységében elemezni. Varga Balázs azonban a felmutató írói-elemzói stratégiáját választja: éles szemmel veszi észre a korábbi leírások elégtelenségét és tömören felhívja az olvasó figyelmét is a szakmán belül közismert jelenségek újszerú magyarázataira vagy 
ismeretlen összefüggésekre, ám nem akarja részletekbe menóen feltárni azokat, mintegy rábízza a jövố kutatóira, hogy hosszú adatsorokkal, összehasonlító vizsgálatokkal még alaposabban támasszák alá meglátásait. A választott vagy a kiadó által biztosított terjedelmen belül nincsen mód felvetett problémák részletes kifejtésére, viszont a felmutatás is sok esetben megvilágító erejú.

A kötet egyik legfốbb erénye az elemzésekben megmutatkozó rugalmas gondolkodásmód: Varga Balázs szembemegy a filmtörténetírás és a filmkritika közhelyszerúen ismételt megállapításaival és megcsontosodott gyakorlataival, ezek helyett új szempontokat keres, a történeti jelenségek és fejlemények okainak sokféleségét állítja az olvasó elé. Varga érvelésében felfedezhetô állandó mintázat, hogy felveti a bevett vélekedést egy-egy kérdéssel kapcsolatban, majd igyekszik cáfolni vagy árnyalni azt más szempontokat felvetô elemzéseivel. „A Kádár-korszak évtizedeinek magyar filmjét általában szerzôi filmes paradicsomként szokás jellemezni. Olyan közegként, amelyben a népszerú filmkultúra komoly hendikeppel küzdött" (115) - írja a szerzô. Aztán azonnal rámutat arra, hogy csupán a kánonból hiányoznak a populáris filmek, miközben „a nyolcvanas évek például kifejezetten a népszerú filmkultúra és a múfaji filmkészítés reneszánszát hozta.” (115) Ezt azzal támasztja alá, hogy rámutat a nyugati koprodukciók és populáris kísérletek jelentôségére az évtizedben. Némi kritika azonban ezt az érvelést is megilleti: nem ártott volna számokkal is megerôsíteni az állítást, kimutatni, hogy az elkészült filmek arányában hány film sorolható a populáris filmkultúra alkotásai közé, milyen nézôszámokat értek el ezek a filmek, s hogyan viszonyul ez az arány a hatvanas évek számaihoz. Ha ezek az adatok el is maradnak, valamivel késôbb meggyôzoó érvet szolgáltat állításához, amikor a nyolcvanas évek múfaji sokszínúségét illusztrálja (126).

Amint az elôbbi illusztrációm is elárulja, a második rész egyik megvilágító erejû fejezetének a populáris filmrôl szóló egységet tartom. A szerzô e témakörben a trendeket, folyamatokat, múfaji jellegzetességeket felismerő érzékenységét és filmtörténeti tudását nagyívúen demonstrálja. A választott adatok meggyőzően bizonyítják a többek által hangoztatott nézetet, hogy a magyar filmból igazán a midcult hiányzik; Varga ezt a 20-80 ezer közti nézôszámot elérô magyar filmek alacsony számával bizonyítja be (136-137.). A szerzô állítása, hogy a magyar filmkultúrában megvannak a szerzői filmek és az amerikai mintákat követô populáris filmek, ám hiányoznak a középfajú filmek, amelyek „az otthonosság és felismerhetôség tapasztalatára” (182) építenek. A populáris filmrốl írott fejezet konklúziója a magyar film Magyarország-képének szentelt utolsó fejezet, következésképpen az egész könyv konklúziójával rezonál: „oly sok magyar film nem tud igazán otthon lenni. Akkor pedig miért és hogyan várjuk, hogy a nézók is felismerjék magukat bennük?" (182).

A másik két megvilágító erejú, egymással összefüggő fejezet a kanonizáció és a nemzetközi filmfesztiválok kérdéseit taglalja. Tanulságos szembesülni azzal, hogy a magyar filmszakmai kanonizáció adott esetben mennyire eltér a nemzetközitôl, hogyan hat vissza az utóbbi az elôbbire, míg a fordított esetre érthetô módon nincsen példa. A kanonizáció folyamatait Varga a nemzetközi filmfesztiválok elméletéhez kapcsolja. A közép-európai filmek 1990-es évekbeli cannes-i mélyrepülésével hozza összefüggésbe az évtized elején ígéretesen induló nemzetközi 
rendezői karrierek megszakadását, miközben arra is rámutat, mennyi tényezô játszik-játszhat ebben szerepet. A fesztiválok elméletének bevonásával segít megértenünk, hogyan lovagolhatta meg a 2000 körül színre lépó fiatal rendezôcsapat a fesztiválok újabb hullámait. Mundruczó Kornél pályáján keresztül pedig meggyőzően demonstrálja, hogy egy ügyes, a fesztiválok szerepét idejekorán felismerô fiatal rendezô hogyan kovácsolhat trendérzékeny filmek során át nemzetközi karriert. (Kár, hogy a szerzô itt nem jelöli meg pontosan, amire korábban, a 173. oldalon utal, hogy Mundruczó 2003-ban részt vehetett a Cannes-i Filmfesztivál Résidence programjában, amely a leendő fesztiválfilmek és fesztiválfilmesek iskolája.)

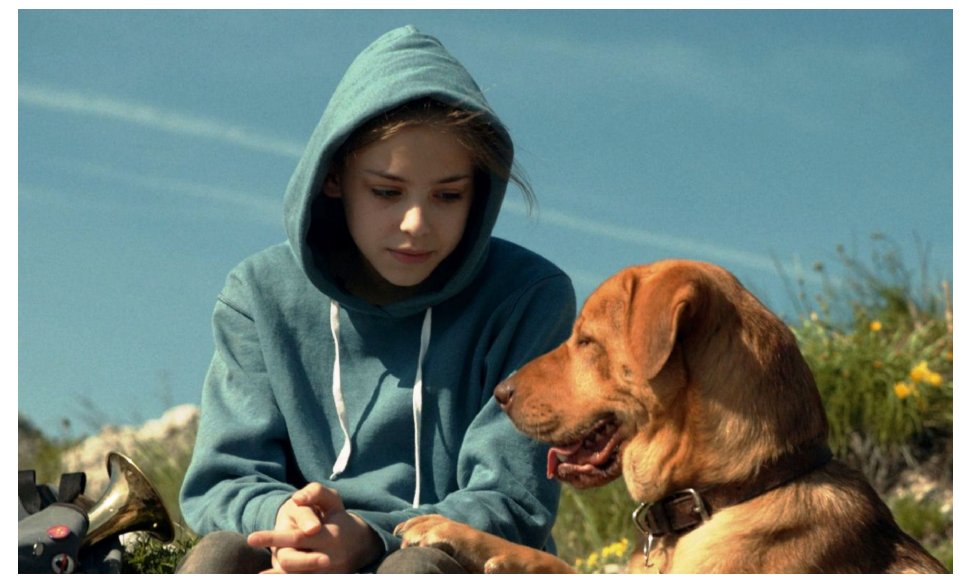

Fehér isten (Mundruczó Kornél, 2015)

Nézzünk egy olyan fejezetet a második részből, amelynek gondolatmenete hiányérzetet keltett és vitára sarkallt! A magyarországi adókedvezménnyel elôsegített bérmunkát vizsgáló fejezetnek már a címe is árulkodó (Szervízmunkák - a magyar film szolgálatában), a következtetései egyértelmúen csak a szervízmunkák pozitív hatását hangsúlyozzák: a külföldi stábok hazai pénzköltését, a forgatások turisztikai értékét, a filmiparra nézvést pedig a filmes infrastruktúra kiépülését és modernizációját, a tudástranszfert és a magyar filmes szakemberek alkalmazását (101). Eleve kérdéses, hogy valóban többet költ-e egy stáb a nekik juttatott adókedvezménynél, erre vonatkozóan nincsen hivatkozott kutatás a szövegben. Fogadjuk azonban el a szervízmunkák adókedvezménnyel való támogatását megokoló hivatalos érvelést, amit Varga is megismétel, hogy az országnak gazdaságilag megtérül a befektetés (97). Joó Tamás doktori disszertációjában más szempontokat vet fel, amelyek kérdésessé teszik, hogy az államnak 20-25\% adókedvezménnyel kell-e támogatnia nagy hollywoodi stúdiók magyarországi forgatásait. A legfontosabb szempontja, hogy a magyar szakemberek többnyire alacsony hozzáadott értéket képviselő munkakörökben jelenhetnek meg a forgatásokon, díszletépítôként, világosítóként, asszisztensként, nem pedig forgatókönyvíróként, rendezôként, így aztán a világ vezető filmiparától való lemaradásunk megmarad. A hollywoodi produkciók itthoni forgatásai ugyan tudástranszfert eredményeznek, ám kérdéses, hogy az így elsajátított tudást képesek-e megfizetni a magyar produkciók, ugyanis „a magyar közpénzből bôkezúen támogatott tengerentúli tulajdonos vagy megbízó munkái a magasabb gázsikkal elvonja legjobban képzett és / vagy legtapasztaltabb magyar munkaerốt a kisebb európai vagy magyar állami vagy független produkcióktól, koprodukcióktól.”[25] Leegyszerúsítve a kérdést, vajon milyen módon lehetett volna a magyar filmkultúra szolgálatában, 
a hazai film versenyképességét fejlesztve elkölteni a Die Hard 5-re juttatott kb. 2 milliárd forintos állami támogatást? ${ }^{[26]}$ A fenti ellenvetéseket azért hoztam, mert bár a szervízmunkák számos pozitívumát kevesen kérdójelezik meg, egy elfogulatlan elemzésnek több oldalról is érdemes lett volna körbejárni a mai magyar filmipart mélyen átható jelenséget. 
A kötettel szembeni egyik leglényegesebb kritikám talán meglepő módon azzal kapcsolatos, hogy Varga történészi érvelésében és történeti narratívájában számos pontot nem vagy nem megfelelôen támaszt alá forrásokkal, hivatkozásokkal. A kutatás részben jelentôs mennyiségú adattal dolgozik, részben a filmtörténetírás gyarapodó számú elméleti szövegeire (fesztiválok, filmfinanszírozás stb.) támaszkodik, a tények megállapítása és a következtetések levonása mégsem mindig követi a tudományos múvekkel szembeni elvárásokat. Lássunk néhány példát azokra az esetekre, amikor az érvelést hitelteleníti a hivatkozás hiánya! A szerzó az oknyomozó riporterekhez méltó módon tárja fel a helytelen, időnként korrupt gyakorlatokat, ám hiányzik a forrás és a konkrét példa, amely alapján elhihetjük neki a leleplezést: „Több példa is volt arra, hogy a stúdió vezetôi nem a kuratórium által ajánlott, kiemelt filmet (filmeket) készítették el a csomagtervre kapott támogatásból, hanem más, a támogatásban nem priorizált filmet (adott esetben a stúdióvezetô saját filmjét).” (37) A következô kérdések merülnek fel: Melyik stúdió, melyik vezetôje? Milyen filmekrôl volt szó a csomagtervben? Melyik filmterv nem kapott támogatást? A források hiányát betudhatjuk annak, hogy az MMA-t felszámolták, dokumentációja nem maradt meg (?), hogy honlapja eltûnt a világhálóról a rajta levô adatokkal együtt, hogy a csomagtervek nem voltak publikusak, s hogy Varga szóbeli értesülést szerzett ezekrôl a múltbéli rossz gyakorlatokról. Akárhogy is történt, hivatkoznia kellene az információ forrására. ${ }^{[27]}$ Egy másik ponton arról ír, hogy „az évtized közepén a hazai DVD-piac nagyságát is legalább a mozipiaccal azonosnak becsülték az elemzések" (109). Furcsa, hogy egyetlen elemzés hivatkozási adatait sem adja meg ennek a fontos állításnak az alátámasztásául. Varga a filmbemutatás kapcsán felhívja a figyelmet arra, hogy a moziforgalmazás mellett a DVD-eladásokat, televíziós vetítéseket és torrentletöltéseket is bele kellene számítanunk a nézettségbe. „Tanulságos azonban a kortárs magyar filmkultúráról való beszédnek ez a vakfoltja: hogy úgy próbálunk magyar filmekről értekezni, hogy közben kevés fogalmunk van arról, hogy vajon ténylegesen milyen közönség, hol, milyen platformon, milyen formában nézi ezeket a filmeket.” (110) Ha már felvetette a kérdést, érdemes volna összehasonlításként más országokban zajló vizsgálatokat beidéznie, vajon Európa más nemzeti filmiparaiban milyen módszerekkel próbálják, tudják a szakemberek (filmközgazdászok, filmszociológusok, filmtörténészek) összesíteni a nézôszámokat és milyen tanulságos eredményekre jutnak. A három évtized háromféle filmkultúrájának értékelésében az MNF-rôl azt írja, hogy „a múködése és az elfogadottsága javult” (68), amelyet megint csak nem támaszt alá számokkal, filmkészítókkel készített nyilvános- vagy háttérinterjúk megállapításaival. Számos további ponton igényeltem volna (erôsebb) bizonyítékokat, hivatkozásokat, de nem idézek több példát. Kritikám azért érinti a források kérdését, mert Varga Balázs könyve nagy részében óriási befektetett munkával, nehezen hozzáférhetô, primér adatokat feldolgozó alapkutatást folytatott, ám a munka eredménye, a kezünkben tartott könyv számos esetben hagy kétségek között a leírt állítások igazságával kapcsolatban.

Recenziómat azzal a bevett fordulattal zárhatnám, hogy a Filmrendszerváltások igazi hiánypótló kötet. Valóban, a hatalmas kutatómunka nyomán megírt monográfiának hála a rendszerváltás utáni magyar film történetérôl immár jóval többet tudunk. Ám Varga Balázs könyve egyszerre 
több és kevesebb is hiánypótlásnál. Több, amennyiben módszert is kíván nyújtani a filmtörténészeknek egy-egy korszak feldolgozásához, arra, hogyan ötvözhetik korszerúen az intézménytörténetet a szerző- és múfajcentrikus filmtörténetek bevett narratíváival. Ugyanakkor kevesebb, amennyiben egyetlen érintett területet sem kíván maradéktalanul feltárni, „hézagmentesen bevarrni” a további kutatások elôtt. Felmutat és új diskurzust nyit meg. Gondolkodásra sarkall és vitára provokál.

1. Szekfü András: Filmes múltunk jövôje. Beszélgetés Ráduly Györggyel. Filmvilág, 2017/4. 26-29.

2. Joó Tamás: Nemzetközi produceri ismeretek. Filmfinanszírozás és filmpolitika. Doktori értekezés. Budapest, Színház- és Filmmúvészeti Egyetem, 2016. http://szfe.hu/wp-content/uploads/2016/11/Jo\%C3\%B3Tam\%C3\%Als-DLA-dolgozat.pdf

3. Foktôi János: Az állam szerepe a magyar filmmüvészet és filmipar 2004 és 2014 közötti alakulásában, különös tekintettel a mozgóképörökség megôrzésére és hasznosítására. Doktori értekezés. Budapest, Színház- és Filmmúvészeti Egyetem, 2016. http://szfe.hu/wp-content/uploads/2017/02/Fokt\%C5\%91i-J\%C3\%AlnosDLA-dolgozat.pdf

4. Írásomban hangsúlyos szerepet kap az MMK és az MNF könyvbéli értékelésével kapcsolatos kritikám, ezért szükségesnek tartom megemlíteni, hogy négy éven át az MMK Dokumentumfilmes Szakkollégiumának tagja voltam.

5. A kötetből vett idézetek oldalszámát nem külön hivatkozásban, hanem zárójelben jelzem.

6. James Chapman: Film and History. London, Palgrave, 2013. 19-21.

7. Teljesen más értelemben használja a kognitív teória az ökológiai elmélet fogalmát. Lásd Joseph Anderson - Barbara Anderson: Miért van szükség ökológiai metaelméletre? Metropolis, 1998/4.

8. Jon Dovey: Documentary Ecosystems. Collaboration and Exploitation. In Kate Nash - Craig Hight Catherine Summerhayes (szerk.): New Documentary Ecologies. Emerging Platforms, Practices and Discourses. London, Palgrave Macmillan, 2014. 11-32.

9. Nagyon fontos utalást tesz a szerzô arra, hogy a fiatal film és a fiatal filmkritikus-nemzedék egymást segít(h)ette (volna), ám végül is elmarad e generáció bemutatása és az is, hogy vajon az együttmúködés megtörtént-e vagy sem. (145-146.)

10. A Színház- és Filmmúvészeti Egyetem rendezô szakos hallgatóinak a kötetben megtörtént alapos leírásán túl a különböző egyetemek filmelméleti-filmtörténeti képzéseinek áttekintése adhatott volna képet erről.

11. Késôbb nevezték át Magyar Mozgókép Közalapítvánnyá (MMK).

12. http://hvg.hu/itthon/20101228_alapitvanyokat_szuntet_kormany

13. Vitatható módon a fenti állítást a szerzô Kovács András Bálint egyik polemikus cikkével is alátámasztja, miközben Kovács a Vajna-féle MNF Filmszakmai Döntóbizottságának a tagja, tehát az MNF-fel (következésképpen az MMK-val) szembeni elfogulatlansággal a legkevésbé sem lehet vádolni, ugyanakkor a hosszan idézett részlet megítéléséhez szükséges ezen fontos információ nem kerül említésre a könyvben.

14. Lásd Stôhr Lóránt: Érzelmek kiáradása. Sós Ágnes dokumentumfilmes pályája az intézményrendszer tükrében. Apertúra, 2016. nyár https://www.apertura.hu/2016/nyar/stohr-erzelmek-kiaradasa-sos-agnesdokumentumfilmes-palyaja-az-intezmenyrendszer-tukreben

15. Foktői: i.m. 123.

16. Foktôi: i.m. 121.

17. Joó: i.m. 13.

18. Uo. 14. 
19. Foktői: i.m. 131-132.

20. http://mnf.hu/hu/palyazatok/nyertes-palyazatok?filter=zene+n $\% \mathrm{C} 3 \% \mathrm{~A} 9 \mathrm{k} \% \mathrm{C} 3 \% \mathrm{BCl}$

21. http://mnf.hu/hu/palyazatok/nyertes-palyazatok?filter=Viszkis

22. http://mnf.hu/hu/palyazatok/nyertes-palyazatok?filter=Kincsem

23. Joó: i.m. 126-127.

24. Joó Tamás az európai filmfinanszírozási modelleket hasonlítja össze és az európai összehasonlításban már közel sem tûnik a legjobbnak az MNF struktúrája és döntéshozatali mechanizmusa. Lásd Joó: i.m.

25. Joó: i.m. 63.

26. Joó: i.m. 119.

27. Az utóbbi években az MNF-fel kapcsolatban is jócskán értesülhettünk hasonló történetekrôl, számos esetben dokumentált módon, nyilvános interjú formájában, de háttérbeszélgetéseken is sok mindent hallhatunk parkolópályára állított rendezőkrôl. Filmtörténészként, filmkritikusként sajnálom, hogy ezek már nem kerülhettek be az MNF értékelésébe. Lásd a legújabbakat: https://444.hu/2017/10/21/palfigyorgy-szerint-schmitt-mariaek-nem-engedtek-ki-kulfoldi-fesztivalokra-a-kisfilmjeit-nehogyosszevissza-nyilatkozgasson-a-kormanyrol

\section{Irodalomjegyzék}

- Anderson, Joseph - Anderson, Barbara: Miért van szükség ökológiai metaelméletre? Metropolis , 1998/4.

- Chapman, James: Film and History. London, Palgrave, 2013.

- Dovey, Jon: Documentary Ecosystems. Collaboration and Exploitation. In Kate Nash - Craig Hight - Catherine Summerhayes (szerk.): New Documentary Ecologies. Emerging Platforms, Practices and Discourses. London, Palgrave Macmillan, 2014. 11-32.

- Foktói János: Az állam szerepe a magyar filmmüvészet és filmipar 2004 és 2014 közötti alakulásában, különös tekintettel a mozgóképörökség megörzésére és hasznositására. Doktori értekezés. Budapest, Színház- és Filmmúvészeti Egyetem, 2016. http://szfe.hu/wpcontent/uploads/2017/02/Fokt\%C5\%91i-J\%C3\%Alnos-DLA-dolgozat.pdf

- Joó Tamás: Nemzetközi produceri ismeretek. Filmfinanszírozás és filmpolitika. Doktori értekezés. Budapest, Színház- és Filmmúvészeti Egyetem, 2016. http://szfe.hu/wpcontent/uploads/2016/11/Jo\%C3\%B3-Tam\%C3\%Als-DLA-dolgozat.pdf

- Stőhr Lóránt: Érzelmek kiáradása. Sós Ágnes dokumentumfilmes pályája az intézményrendszer tükrében. Apertúra, 2016. nyár https://www.apertura.hu/2016/nyar/stohrerzelmek-kiaradasa-sos-agnes-dokumentumfilmes-palyaja-az-intezmenyrendszer-tukreben

- Szekfü András: Filmes múltunk jövôje. Beszélgetés Ráduly Györggyel. Filmvilág, 2017/4. 26-29

- Varga Balázs: Filmrendszerváltások. A magyar játékfilm intézményeinek átalakulása 1990-2010. L'Harmattan, Budapest, 2016

\section{Filmográfia}

- A Viszkis (Antal Nimród, 2017)

- Die Hard - Drágább, mint az életed (A Good Day to Die Hard. John Moore, 2013) 
- Kincsem (Herendi Gábor, 2017)

- Pappa pia (Csupó Gábor, 2017) 
(C) Apertúra, 2017. Ỗsz | www.apertura.hu

webcím: https://www.apertura.hu/2017/osz/stohr-egy-kozep-europai-vegetacio-leirasa/

https://doi.org/10.31176/apertura.2018.13.1.2

$$
\text { (2) opertúro }
$$

